Summer 2013

\title{
Gender and Global Lawyering: Where are the Women?
}

Steven A. Boutcher

University of Massachusetts, boutcher@soc.umass.edu

Carole Silver

Indiana University Maurer School of Law, c-silver@law.northwestern.edu

Follow this and additional works at: https://www.repository.law.indiana.edu/ijgls

Part of the Civil Rights and Discrimination Commons, Law and Gender Commons, Law and Society Commons, and the Legal Profession Commons

\section{Recommended Citation}

Boutcher, Steven A. and Silver, Carole (2013) "Gender and Global Lawyering: Where are the Women?," Indiana Journal of Global Legal Studies: Vol. 20 : Iss. 2 , Article 19.

Available at: https://www.repository.law.indiana.edu/ijgls/vol20/iss2/19

This Symposium is brought to you for free and open access by the Law School Journals at Digital Repository @ Maurer Law. It has been accepted for inclusion in Indiana Journal of Global Legal Studies by an authorized editor of Digital Repository @ Maurer Law. For more information, please contact rvaughan@indiana.edu.

\section{$\Psi$}

JEROME HALL LAW LIBRARY

INDIANA UNIVERSITY

Maurer School of Law
Bloomington 


\title{
Gender and Global Lawyering: Where are the Women?
}

\author{
STEven A. Boutcher \& CAROLE SILVER*
}

\begin{abstract}
The dual forces of globalization and support for diversity in the legal profession are responsible for significant growth among U.S. law firms. Both women lawyers and those educated outside of the U.S. have been important elements facilitating the global trajectories of U.S. firms, but the interaction between the two has not been the subject of substantial research. We address this gap by drawing on an original dataset of lawyer biographies, and consider whether career strategies that involve the international mobility of lawyers are equally powerful for women and men. Our research suggests that globalization of large firm practice has not erased gender inequality, and, in fact, may have reinforced and strengthened existing gender disparities.
\end{abstract}

\section{INTRODUCTION}

The dual forces of globalization and support for diversity in the legal profession are responsible for significant growth among U.S. law firms: ${ }^{1}$

* Steven A. Boutcher is an Assistant Professor, Department of Sociology and Public Policy, University of Massachusetts, Amherst. Carole Silver is a Professor of Law, Indiana University Maurer School of Law-Bloomington; as of January 2014, Silver will be Professor of Global Law \& Practice, Northwestern University Law School. The authors thank Fred Aman for his support for our work on gender and globalization, the participants in the Law \& Society international working group on gender and global legal practice, and Matthew Antonini for research assistance. Earlier versions of this article were presented at the annual meeting of the Law \& Society Association, Honolulu, June 2012, and at the American Bar Foundation Research Group on Legal Diversity inaugural meeting, Chicago, May 2012.

1. See Debora L. Spar, Lawyers Abroad: The Internationalization of Legal Practice, 39 CAL. MgMT. REV. 8, 16 (1997) (discussing the growth of global practices); Carole Silver, Globalization and the U.S. Market in Legal Services-Shifting Identities, 31 J.L. \& POL'Y INT'L BUS. 1093 (2000) [hereinafter Silver, Shifting Identities]; Carole Silver, Winners and Losers in the Globalization of Legal Services: Situating the Market for Foreign Lawyers, 45 VA. J. INT'L L. 897 (2005) [hereinafter Silver, Winners and Losers]. Compare BUREAU OF

Indiana Journal of Global Legal Studies Vol. 20, Issue 2 (2013)

(C) Indiana University Maurer School of Law 
female lawyers account for much of the increase in headcount in large law firms over the last several decades, ${ }^{2}$ and lawyers educated and licensed in jurisdictions outside of the United States have helped U.S.-based law firms expand internationally. ${ }^{3}$ Despite the importance of these trends, little attention has been devoted to how these two processes intersect in the study of lawyers and large law firms. ${ }^{4}$ As David Wilkins noted more than ten years ago, "[g]lobalization and diversity are almost never expressly linked beyond the trite (albeit true) observation by diversity advocates in the U.S. that the majority of the world's population is neither white nor male." ${ }^{5}$ Nevertheless, gender (and diversity generally) is a particularly hot topic in the discussions of and by elite law firms, ${ }^{6}$ including global firms. The focus on these issues by a wide range of stakeholders is at least as significant. ${ }^{7}$

ECON. ANALYSIS, U.S. DEP'T OF COM., U.S. International Services: Detailed Statistics for Cross-Border Trade, tbl. 7, Business, Professional, and Technical Services, available at $\mathrm{http}: / / \mathrm{www}$.bea.gov/international/international_services.htm\#detailedstatisticsfor (outlining how exports from U.S. trade in legal services increased from $\$ 3.10$ billion in 2000 to $\$ 7.26$ billion in 2009) with BUREAU OF ECON. ANALYSIS, U.S. DEP'T OF COM., International Economic Accounts, tbl., U.S. International Trade in Goods and Services: Exports, Imports, and Balances, available at http://www.bea.gov/international/index.htm\# trade (under "Trade in Goods and Services," click on "Trade in Goods and Services, 1992-present") (showing that exports from U.S. international trade in goods and services increased from $\$ 1.07$ trillion in 2000 to $\$ 1.83$ trillion in 2010 ).

2. See, e.g., Carrie Menkel-Meadow, Feminization of the Legal Profession: The Comparative Sociology of Women Lawyers, in LAWYERS IN SOCIETY: AN OVERVIEW 196 (Richard L. Abel \& Philip S.C. Lewis, eds., 1996).

3. See generally Carole Silver, Nicole De Bruin Phelan \& Mikaela Rabinowitz, Between Diffusion and Distinctiveness in Globalization: U.S. Law Firms Go Glocal, 22 GEO. J. LEGAL ETHICS 1431 (2009) (examining sixty-four leading U.S. law firms international staffing).

4. An important exception and contribution that we have drawn upon heavily is WOMEn IN THE WORLD's Legal Professions (Ulrike Schultz \& Gisela Shaw eds., 2003), which describes the distinctions between common and civil law jurisdictions as "the most striking divide separating women in the world's legal professions." Introduction to id. at xxviii. The interaction of gender and globalization regarding careers has generated attention among management scholars. See, e.g., Hilary Harris, Global Careers: Work-Life Issues and the Adjustment of Women International Managers, 23 J. MGMT. DEv. 818, 81819 (2004) (estimating that women occupy only between $2 \%$ and $15 \%$ of senior management international assignments, and suggesting that "the impact of gender is likely to be higher in the case of women relocating on an international assignment as a result of work, partner and family considerations but that can be mediated by both organizational and family support").

5. David B. Wilkins, Why Global Law Firms Should Care About Diversity: Five Lessons from the American Experience, in THE InTERNATIONALIZATION OF THE PRACTICE OF LAW 43, 44 (Jens Drolshammer \& Michael Pfeifer eds., 2001).

6. See, e.g., Vivia Chen, Progress for Women-Except at the High End, THE CAREERIST, (June 16, 2011), http://thecareerist.typepad.com/thecareerist/2011/06/wilefs- 
The patterns of growth experienced by large law firms suggest that firms with a global footprint might take their attitudes toward diversity with them as they go global while also adapting to the local environments where they establish offices. This "glocal" structure enables law firms to follow paths that capitalize on two ends of global growth strategies: the diffusion or cross-national convergence paradigm-spreading U.S. norms and practices through services offered overseas-and the national distinctiveness paradigm-adapting their practices to local professional and business norms. ${ }^{8}$ It is an approach characteristic of the ways in which most large, U.S.-based law firms staff their overseas offices, as well as of the expansion patterns of many global businesses. 9 The firms combine U.S.-educated and -licensed lawyers and lawyers with local host country credentials in order to foster their global identities while simultaneously capturing important local knowledge and relationships.

In this article, we examine the relationship between gender diversity and globalization to consider whether career strategies that involve the international movement of lawyers are equally powerful for women and men. Our premise is that globalization may offer some lawyers the potential to gain an advantage in the same way that strategies encompassing global experiences are rewarded in other professions and business generally.10 To consider whether law offers analogous benefits, we focus on the following questions: First, does globalization affect women differently than men in terms of attaining professional status, operationalized here as partnership; is there

32-firms.html (reporting on Women in Law Empowerment Forum and recognizing 32 law firms for promoting women).

7. See, e.g., 2011 Diversity Benchmarking Study: A RePort to Signatory LAW FIRMS, N.Y.C. BAR ASs'N (2012), available at http://www.nycbar.org/images/stories/pdfs /diversity/2011_law_firm_diversity_benchmarking_report.pdf; Barbara Flom, Report of the Seventh Annual NAWL National Survey on Retention and Promotion of Women in Law Firms (October 2012), available at http://nawl.timberlakepublishing.com/files/NAWL \%202012\%20Survey\%20Report\%20final.pdf; Leadership Academy for Women, WORK LIFE LAW: U.C. HASTINGS C.L., http://worklifelaw.org/law/ (last visited Feb. 16, 2013); The Research Group on Legal Diversity, AM. B. FouND., http://www.americanbarfoundation .org/research/The_Research_Group_on_Legal_Diversity.html (last visited Mar. 1, 2013).

8. See Silver et al., supra note 3, at 1432.

9. See id. at 1456-59.

10. See, e.g., Morgan W. McCall, Jr. \& George P. Hollenbeck, Developing GLOBAL EXECUTIVES 9 (2002) ("Learning to work across cultures is an essential competency of the global executive, and it is for most people an emotional education as well as an intellectual one. . . Considering the intellectual complexity of the business lessons and the transformational quality of the personal lessons, we conclude that global executives do indeed have a broader perspective than their domestic counterparts. This unique perspective underlies the elusive quality called a global mind-set."). 
evidence of a global "bump" in law as in other fields, where a career advantage results from taking an overseas assignment? ${ }^{11}$ Second, how does the goal of gender diversity travel as law firms increasingly become global actors; do firms reproduce the same patterns of gender diversity as they reach past national boundaries and establish themselves in new communities? We frame these questions in the context of the global growth of U.S.-based law firms, with specific attention to U.S.-educated and -licensed lawyers in this growth. Our focus is on firms that concentrate on corporate clients. Thus, we do not claim our study to be representative regarding non-U.S.-based corporate firms, nor is it necessarily reflective of the force of globalization on practices serving clients outside of the business world.

In the sections that follow, we use an empirical lens to investigate the relationship between globalization and gender, drawing from an original dataset collected by Silver, Phelan, and Rabinowitz that contains biographical information about individual lawyers working overseas in a sample of U.S.-based law firms. ${ }^{12}$ Below, we analyze the relationship between gender and professional status in these elite global practice environments. The remaining sections of the article are organized as follows: First, we situate our study within two distinct literatures on global legal practice and gender diversity in large law firm practice. Next, we discuss our data and analytical approach, followed by the results of our analysis. Finally, we suggest next steps in research to deepen the understanding of globalization's influence on gender inequality in legal practice.

11. Consider, however, evidence that women do not share equally in global opportunities in other fields. See Rueyling Tzeng, Gender Issues and Family Concerns for Women with International Careers: Female Expatriates in Western Multinational Corporations in Taiwan, 21 WOMEN MGMT. REV. 376, 377.78 (2006) ("[F]oreign postings-usually considered positive indicators of career advancement, salary increases, and managerial appointments as well as required experience for positions in corporate senior management-are rarely given to women. Even though the percentage of female expatriates working in the overseas offices of American-based multinational firms has increased from [3\%] in 1983 (Adler, 1984) to [14\%] in the late 1990s (Koretz, 1999), that figure is still quite low as women account for approximately [30\%] of all American MBA students (Koretz, 1999) and about [50\%] of managers and professionals in US corporations (Catalyst, 2000). The fact that the number of women working overseas is increasing at a much lower rate than the number of women entering their respective domestic labour markets (Moran and Riesenberger, 1994) suggests that women pursuing international careers are more likely to encounter gender discrimination and family responsibility issues than their domestic counterparts.").

12. We acknowledge with gratitude the work of many students who helped with the data gathering; in addition, coding and analysis was also conducted by Sarah Babbitt, among others. 


\section{Situating the Nexus BetweEn Research on Globalization and GENDER IN LEGAL PRACTICE}

\section{A. The Globalization of Legal Practice}

The process of globalization has transformed economic activity and exerted a substantial influence on supporting services, including legal services. The description of globalization's influence on the work of lawyers in 2007 by Karl Ege, then Vice Chairman and Senior Adviser of Russell Investments and Chairman of Russell Trust Company, offers insight into how globalization permeates the work of the corporate sector of the economy:

In 2007, for the first time, more than half of the aggregate revenues of the companies comprising the S\&P 500 index (which includes only companies with headquarters legally domiciled in the United States) were generated from operations outside the United States. This dramatic increase in the globalization of American business is reflected in nearly all sectors of our national commercial fabric, from pharmaceutical firms, to the automobile industry, from high tech to low tech to no tech. Our services industry, which now represents over $70 \%$ of our nation's gross domestic output, is increasingly global in scope, as we offer engineering, consulting, architectural, legal and financial services to an increasingly global client base. For the lawyers representing companies engaged in the global marketplace, their practices have become global as well. ${ }^{13}$

Lawyers and law firms representing (or wishing to advise) businesses with extensive global activities (as well as businesses planning for global growth) have developed their own global strategies. Some have created firm-specific international networks by opening overseas offices, while others participate in formal or informal external networks with independent law firms in order to extend their

13. Karl Ege, Vice Chairman \& Senior Adviser of Russell Invs, \& Chairman of Russell Trust Co., Address to the Cornell Law School Annual Lunch in New York City: Reflections on Globalization of the Legal Practice: A 35-Year Journey-1972-2007 (Feb. 1, 2008), http://www.lawschool.cornell.edu/spotlight.cfm?pageid=100640. 
geographic coverage beyond their locale. ${ }^{14}$ For law firms that have followed the former approach, the evolution from national to global organizations has been based on an ability and willingness to move beyond national borders with regard to experts and expertise. U.S.-based law firms, for example, have added to their ranks lawyers, educated and licensed outside of the United States, whose expertise provides credibility to their firms for advising on matters not governed exclusively by U.S. law. ${ }^{15}$ Deborah Spar described the early growth beyond U.S. law expertise, ${ }^{16}$ while John Flood characterized the firms' roles as 'sanctifiers,' moving well beyond the national law focus of their beginnings. ${ }^{17}$

In order to develop global identities in this way, firms were aided by regulation in their host jurisdictions, ${ }^{18}$ as well as at home. ${ }^{19}$ The most supportive form of regulation authorized the firms to combine local lawyers educated and licensed in the host jurisdiction with U.S. and other nonlocal lawyers. ${ }^{20}$ Prior to the 1990 s, it was common for national

14. See, e.g., LEXMUNDI: WORLD READY, http://www.lexmundi.com/lexmundi/default. asp (last visited Mar. 1, 2013); TAGLAw, http://www.taglaw.com/ (last visited Mar. 1, 2013); TERRA LEX, http://www.terralex.org/ (last visited Mar. 1, 2013). Increasingly, firms pursue both, particularly for purposes of 'covering' jurisdictions that have not authorized a local presence by U.S.-based and other nonlocal firms. See Carole Silver, David Van Zandt \& Nicole De Bruin Phelan, Globalization and the Business of Law: Lessons for Legal Education, 28 NW. J. INT'L L. \& BUS. 399, 399 (2008); Silver, Winners and Losers, supra note 1 , at $915-17$.

15. See Silver et al., supra note 3 , at 1469.

16. See Spar, supra note 1 , at 16 ("In foreign markets, law firms have to compete through specialization . . . They started with their obvious specialty, counseling foreign clients on the intricacies of U.S. law and corporate practice. Then they segued into increasingly specific areas of corporate strategy, advising clients on topics such as acquisitions, hostile takeovers, and debt restructuring-complicated corporate maneuvers that had all been developed first in the U.S. and British markets. As these sorts of deals proliferated across the international economy, U.S. and British firms found themselves with a natural, lucrative niche.").

17. John Flood, Lawyers as Sanctifiers: The Role of Elite Law Firms in International Business Transactions, 14 IND. J. GLoBAL LEGAL STUD. 35, 39-40 (2007).

18. In this article, "host" jurisdiction refers to the country in which the firm is operating outside of the firm's home country. For a U.S.-based firm with an office in London, for example, England is the "host" jurisdiction where the London office lawyers work.

19. In this article, we identify the "home" jurisdiction for law firms as that jurisdiction in which the firm was first created. For certain firms resulting from a transatlantic merger, for example, such as Hogan Lovells, this presents a challenge. Since the study reported on here is focused on the global activities of U.S.-based law firms, we consider each of the firms included in our sample to have the United States as its home country.

20. See Mihaela Papa \& David B. Wilkins, Globalization, Lawyers, and India: Toward a Theoretical Synthesis of Globalization Studies and the Sociology of the Legal Profession, 18 INT'L J. LEGAL PROF. 175, 177 (2011) (describing three globalization processes related to 
regulation to prohibit such combinations. Local lawyers generally practiced only with local organizations and global firms limited themselves to practice carried out by their home country lawyers, sometimes supplemented by several lawyers from a third country. ${ }^{21}$ The important dividing line resulting from early regulation separated host country lawyers from expatriate ("expat") lawyers. While such regulatory barriers today remain in certain jurisdictions such as India, in many of the hubs of economic activity global law firms now are able to establish offices, hire local lawyers, and bring in U.S. expats to advise on their areas of expertise, including local and U.S. law. Indeed, certain countries actively court such firms. ${ }^{22}$ In those jurisdictions that authorize U.S.-based firms, among other foreign entities, to practice the law of the host jurisdiction and employ local lawyers, firms tend to take full advantage. There, the offices of U.S.-based law firms may be comprised entirely of locally-educated and -licensed lawyers or include only a marginal presence of U.S. expats. ${ }^{23}$ In other countries, where regulation restricts foreign firms (including those based in the United States) to a more limited practice, there still may be an attempt to gain local expertise. ${ }^{24}$ While host country lawyers may not advise on host country law under such circumstances, ${ }^{25}$ their participation as translators of local regulatory, cultural, political, and economic

the legal profession: economic globalization, globalization of knowledge, and globalization of governance).

21. See Sydney M. Cone, III, International Trade in Legal Services: Regulation of LAWYERS AND FIRMS IN GLobal PRACTICE (2nd ed. 1996); see Silver, Shifting Identities, supra note 1, at $1143 \mathrm{n} .191$ (describing regulatory liberalization in England and related changes in staffing of U.S.-based law firms' London offices by listing firms offering 'U.K. and U.S.-licensed lawyers in London").

22. See, e.g., Anna Stolley Persky, The New World: Despite Globalization of the Economy, Lawyers Are Finding New Barriers to Practice on Foreign Soil, 97 A.B.A. J. 34 (2011), available at http://www.abajournal.com/magazine/article/the_new_world_despite_ globalization_lawyers_find_new_barriers_to_practicing/ ("[S]ome countries, including Singapore, South Korea, Switzerland and even Mongolia, are actively seeking ways to make their court systems more inviting to foreign lawyers and their clients as a way to help build their economies.").

23. See Silver et al., supra note 3, at 1439-43.

24. See Silver, Shifting Identities, supra note 1, at 1142-45; CAROle SILver, GEo. L. Fac. Publications, Research PAPER No. 1519387, EduCating LaWYers for the Global ECONOMY: NATIONAL Challenges 9 (2010), available at http://papers.ssrn.com/sol3/pa pers.cfm?abstract_id=1519387 (also available at Georgetown Law Faculty Publications and Other Works, GEO. L.: THE SCHOLARLY COMMONS, http://scholarship.law.george town.edu/facpub/30/ (last visited Mar. 4, 2013)).

25. See Sida Liu, Globalization as Boundary Blurring: International and Local Law Firms in China's Corporate Law Market, 42 LAW \& Soc'Y REv. 771 (2008) (describing the role of Chinese-licensed lawyers in foreign law firms, working under regulatory barriers to foreign firms' advising on Chinese law). 
challenges may be crucial to a firm's ability to present itself as a knowledgeable and credible advisor.

The pattern of combining host country (or "local") lawyers with expatriate lawyers, including those educated and licensed in the United States, describes the most common approach to staffing overseas offices of U.S.-based firms. For instance, a recent study conducted by Silver, Phelan, and Rabinowitz found that approximately 71 percent of U.S.-based overseas offices were staffed in this way. ${ }^{26}$ Overall, however, U.S. expats comprised only 18 percent of all lawyers working overseas for the firms in their sample. ${ }^{27}$ Despite this, being a U.S. expat carries advantages: 44.2 percent of the U.S. expats were partners, compared to only 27.4 percent of those who were not U.S. expats (which includes local lawyers and non-U.S. expats). ${ }^{28}$ Thus, U.S. expatriate status can be identified as an important source of social capital that carries value in the global legal market. Based on the disproportionate representation of expats among the partners of overseas office lawyers, it appears that U.S.-based firms continue internally to identify with the United States, preferring U.S. legal education as an entrée to advancement.

\section{B. Gender and Global BigLaw}

Since the early 1990 s, when women represented approximately half of entering law school classes, ${ }^{29}$ the proportion and roles of women in large law firms have been a focus of many scholars of the legal profession. ${ }^{30}$ This rich literature tackles a wide variety of questions

26. Silver et al., supra note 3 , at 1456 . The study sample was comprised of 64 U.S.-based law firms that supported a total of 376 offices overseas, which together housed over 8,700 lawyers. Id. at 1437 .

27. Id. at 1448 .

28. Id. at 1459 , Fig. 10

29. See Judith S. Kaye \& Anne C. Reddy, The Progress of Women Lawyers at Big Firms: Steadied or Simply Studied, 76 FordHAM L. Rev. 1941, 1944 n.6 (2008) ["In 1966 to 1967 , women made up $4.3 \%$, or 2520 candidates, of the total enrollment in American Bar Association (ABA) schools. See ABA, First Year and Total J.D. Enrollment by Gender, 1947-2005 (n.d.), available at http://www.abanet.org/legaled/statistics/charts/stats\%20\%206.pdf. By 1986 to 1987, this number had increased to $40.7 \%$, or 47,920 women J.D. candidates. Id. The upward trajectory continued until 2002 , when it reached a pinnacle of $49 \%$ female candidates, and then hovered-as it continues to do-at a respectable $47 \%$ to $49 \%$. Id."].

30. See, e.g., Elizabeth Chambliss \& Christopher Uggen, Men and Women of Elite Law Firms: Reevaluating Kanter's Legacy, 25 LAW \& Soc. INQUIRY 41 (2000); Jo Dixon \& Carroll Seron, Stratification in the Legal Profession: Sex, Sector, and Salary, 29 LAW \& SoC'Y REv. 381 (1995); Cynthia Fuchs Epstein et al., Glass Ceilings and Open Doors: Women's Advancement in the Legal Profession, 64 FordHAM L. ReV. 295 (1995); Fiona Kay \& Elizabeth Gorman, Women in the Legal Profession, 4 ANN. REV. L. \& Soc. SCI. 299 
about the presence and experiences of women in legal practice. ${ }^{31}$ The general story in the United States has been one of persistent underrepresentation of women lawyers among the higher ranks and leadership positions of firms. ${ }^{32}$ At the same time, women occupy close to half of the associate-level and entry-level positions at large firms. ${ }^{33}$ According to a 2008 news report,

[w]e all know there's a problem. Women represent only 18 percent of partners in the nation's largest law firms, 16 percent of equity partners and fewer than 10 percent

(2008); Joyce S. Sterling \& Nancy Reichman, So, You Want to Be a Lawyer? The Quest for Professional Status in a Changing Legal World, 78 FORDHAM L. REV. 2289 (2010); Eli Wald, The Changing Professional Landscape of Large Law Firms, Glass Ceilings and Dead Ends: Professional Ideologies, Gender Stereotypes, and the Future of Women Lawyers at Large Law Firms, 78 Fordham L. Rev. 2245 (2010). On gender in legal education, see generally ElizABETH MERTZ, The LANGUAGe OF LAW SCHOOL: LEARNING To "THINK LiKe A LAWYER" (2007).

31. On possible differences between men and women lawyers, see CAROL GILLIGAN, IN A Different Voice: PsychologiCal ThEORY AND WOMEn's DeVelopment (1st ed. 1982). For an illustration of these differences, see for example Deborah Rhode, Gender and the Profession: An American Perspective, in WOMEN IN THE WORLD's LEGAL PROFESSIONS, supra note 4, at 3, 5-6 (arguing that the "celebration of gender difference risks not only oversimplifying, but also overclaiming," and suggesting instead the recognition of "difference without universalising its content"); Petra Pasternak, Study Finds Male Lawyers More Overconfident, THE RECORDER (May 12, 2010), http://www.law.com/jsp/ca/ PubArticleCA.jsp?id=1202458076181\&hbxlogin=1\&slreturn=20130204030526 (describing differences in optimism and confidence).

32. Joyce S. Sterling \& Nancy Reichman, Navigating the Gap: Reflections on 20 Years Researching Gender Disparities in the Legal Profession, 9 FLA. INT'L UNIV. L. REV. 1 (2013); RONit Dinovitzer et AL., AFTER THE JD II: SECOND RESUltS FROM A NATIONAL STUDY OF LEGAL CAREERS 63 (2009), available at http://www.law.du.edu/documents/direct ory/publications/sterling/AJD2.pdf ("[W]e find that there is a substantial gender disparity in the rates of equity and nonequity partnership. . . AJD2 lawyers are still relatively junior, so that across the sample just over $11 \%$ of respondents have become equity partners, and another $11 \%$ nonequity partners. ... [T] hese low rates of partnership are also the result of the lengthening of the time to partnership, with many partnership decisions today being made after 8-10 years in practice. In the smallest firms, where new lawyers have the highest rate of partnership at this stage of their career, $17 \%$ of women have made equity partner compared to $24 \%$ of men. This disparity persists as firm size increases, with women attaining equity partnership at less than half the rate of men."). See also Rachel Emma Silverman, Jack Welch: "No Such Thing as Work-Life Balance", WALL ST. J. (July 13, 2009, 10:47 PM), http://blogs.wsj.com/juggle/2009/07/13/jack-welchno-such-thing-as-work-life-balance/ ('We'd love to have more women moving up faster,' Mr. Welch said. 'But they've got to make the tough choices and know the consequences of each one.").

33. See Partnership at Law Firms Elusive for Minority Women, NALP (Nov. 8, 2009), http://www.nalp.org/2006partnershipelusiveforminoritywomen (reporting in November 2006 that "[w]omen account for $44.33 \%$ of associates ... [and] $46.67 \%$ of summer associates"). 
of managing partners. At every level of firm practice, including partnership, women are leaving at a much higher rate than their male counterparts. ${ }^{34}$

In 2009 , the numbers were essentially the same. In U.S. offices of elite law firms, "women made up 34 percent of lawyers at the firms we surveyed: 45 percent of nonpartners and 19 percent of partners." 35 Explanations for this are complex and include the structure ${ }^{36}$ and

34. Melissa McClenaghan Martin, Law Firms Create New Models for Diversity, N.Y. L.J. (July 31, 2008), http://www.lawjobs.com/newsandviews/LawArticle.jsp?id=120242338 $9860 \&$ slreturn $=20130405165503$. On the issue of more women than men leaving law practice, however, see DINOVITZER ET AL., supra note 32, at 15 ("Although the existing research literature suggests that women and minorities leave certain sectors of the legal profession at higher rates than their white male peers, we find an unexpected similarity in patterns of job changing across these groups."). The issue of separating equity and nonequity partnership status with regard to gender equality continues to be contentious. See Vivia Chen, What Women Want: Partnership Details, AM LaW DaILY (Feb. 24, 2010, 9:06 AM), http://amlawdaily.typepad.com/amlawdaily/2010/02/what-women-want.html ("Women lawyers are furious, and the legal profession at large doesn't even know it. The reason for the fury: law firms dismissed a request made by the National Association for Law Placement (NALP) for details about partnership structures-namely, a breakdown of equity versus [nonequity] partners in their ranks.").

35. Emily Barker, Stuck in the Middle, AM. LAW (June 1, 2009), http://www.american lawyer.com/PubArticleTAL.jsp?id=1202430856584\&Stuck_in_the_Middle (requiring a LexisNexis subscription).

36. See Wilkins, supra note 5, at 52 ("Elite law firms are structured less like a tennis tournament in that associates do not compete on an equal playing field. Instead, only those associates who get access to good work and supportive developmental relationships have a realistic chance of becoming partners. . . Contrary to the survival of the fittest rhetoric of tournament theory, ... success in large law firms is less a matter of innate ability and hard work - most of those who get hired by elite firms possess these qualitiesand more a function of gaining access to valuable, but limited, opportunities . . that are invariably mediated through relationships."); Patricia Gillette, Cracks in the Ceiling, AM LAW DAILY (Apr. 28, 2009, 5:00 AM), http:/amlawdaily.typepad.com/amlaw daily/2009/04/women.html (arguing that "the economic crisis provides law firms with opportunities ... [which] include: stepping away from the salary and bonus programs that destroyed collegiality and prevented flexibility; making structural and organizational changes long overdue; [and] killing the billable hour once and for all"); Martin, supra note 34 (suggesting that law firm structures explain why women leave: "Work-life issues' are not the primary reason women leave firm practice. As numerous studies have shown, women leave firms because they are dissatisfied with stalled advancement and career opportunities, unsatisfying work and 'unsupportive' work environments. Work-life concerns are certainly a factor in women's decisions to leave, but they are not determinative."); Ed Shanahan, S\&C Promotes Five Associates-Including Four Womento Partner, AM LAW DAILY (Oct. 21, 2009, 6:54 PM), http://amlawdaily.typepad.com/am lawdaily/2009/10/sc-promotes-fiveincluding-four-womento-partner.html ("Firm chairman H. Rodgin Cohen attributes the growth in female partner ranks [announcing that four of the five new partners in the firm are women] to policies, such as flex-time and maternity leave, aimed at promoting and retaining greater numbers of women, the NYLJ's Nate 
professional ideology ${ }^{37}$ of large law firms, and the absence of support mechanisms outside of firms, ${ }^{38}$ among other things. ${ }^{39}$

In their overseas activities, U.S.-based law firms occupy an elite status in the market for corporate-related legal services. These firms serve as sites for the potential transformation of the careers of local lawyers. ${ }^{40}$ As discussed above, experience working for a global firm is an important form of capital generally valued by clients as well as by local law firms. ${ }^{41}$ As a result, global firms offer opportunities to scale local barriers. Practicing with a global firm may help lawyers advance to a more favorable position locally. ${ }^{42}$

Ulrike Schultz and Gisela Shaw found substantial similarity in the overall representation of women in the national legal professions they analyzed, where women generally comprised between one-third and

Raymond reports."); Debra Cassens Weiss, A Law Firm Ditches the Lockstep System and Retains More Women, A.B.A. J. (July 31, 2008, 6:04 PM), http://www.abajournal.com/news /article/a_law_firm_ditches_the_lockstep_system_and_retains_more_women/ (reporting that Husch Blackwell Sanders "replaced lockstep promotions with a system based on competency [and] has seen the percentage of women lawyers leaving the firm drop below that of men.").

37. See Eli Wald, Glass Ceilings and Dead Ends: Professional Ideologies, Gender Stereotypes, and the Future of Women Lawyers at Large Law Firms, 78 FORDHAM L. REV. 2245 (2010) (arguing that the pervading ideology of hypercompetitiveness and the continuance of gender stereotypes makes gender equality even less likely in the foreseeable future).

38. See, e.g., DINOVITZER ET AL., supra note 32; Rhode, supra note 31, at 13 (identifying as "myths of choice" the notion that "women have different family priorities than men and that these personal commitments exact a professional price," and arguing that "[w]omen's career sacrifices are attributable not just to women's choices but to men's choices as well").

39. See Rhode, supra note 31, at 12-13 (noting that men are not solely responsible for "patterns of prejudice; women can be perpetrators as well as targets of bias."); Kenneth G. Dau-Schmidt et al., Men and Women of the Bar: The Impact of Gender on Legal Careers, 16 MICH. J. GENDER \& L. 49, 87-88 (2009) (describing findings from research conducted by Hagan \& Kay (see JOHN HAGAN \& FTONA KAY, GENDER IN PRACTICE: A STUdY OF LAWYERS' LIVES (1995)) and by Epstein (see Epstein et al., supra note 30), among others); Hilary Sommerlad, The Commercialism of Law and the Enterprising Legal Practitioner: Continuity and Change, 18 INT'L J. LEGAL PROF. 73, 96 (2011) ('The legal profession . . is saturated in class, ethnicity and gender, and daily engaged in (re-)producing the meaning of these categories.").

40. See Yves Dezalay \& Bryant G. Garth, Dealing in Virtue (1996) (arguing that international commercial arbitration is a mechanism for transforming careers of lawyers from locally bounded to international); Liu, supra note 25 (exploring how global law firms offer a means of transforming local careers into global careers).

41. See Carole Silver, The Variable Value of U.S. Legal Education in the Global Legal Services Market, 24 GEO. J. LEGAL ETHICS 1 (2010).

42. See generally Christine M. Beckman \& Damon J. Phillips, Interorganizational Determinants of Promotion: Client Leadership and the Attainment of Women Attorneys, 70 AM. SoC. REv. 678 (2005) (exploring gender in the context of the relationship of client leadership and law firm leadership). 
one-quarter of lawyers nationally. ${ }^{43}$ But the practice settings where women are most likely to work are not necessarily those most directly involved in global practice; Schultz and Shaw report, for example, that "in Germany [women] are more likely to be sole practitioners, in Japan it is small law firms that provide most posts for women lawyers." 44 They also considered the role of national regulation on women in legal practice. Despite important distinctions, it was not clear that the regulations had produced significantly different outcomes in terms of women's roles in the profession. Instead, other factors appeared to be at work, such as what Eli Wald characterizes as the professional ideology of "hypercompetitive meritocracy," which disproportionately affects women. 45

Analyzing the presence of women lawyers in global firms outside of the United States is complicated by several factors. First, corporate law firms do not necessarily occupy the same high status position in each jurisdiction. Top law graduates in Germany, for example, traditionally have preferred positions in the judiciary to private practice. ${ }^{46}$ Second, career strategies that feed into global law firms may be less common for women. For example, lateral hiring is a frequent mechanism for building overseas offices, as well as growth in the United States. ${ }^{47}$ But women have been reported as unequal participants in the lateral hiring market. As a result, growth by lateral hiring may exclude women. For young lawyers and relatively new graduates, an alternative entry path may follow a period of study in the United States in a graduate law program. This raises the issue of mobility generally, which may be experienced by women differently than by men, depending upon the

43. Ulrike Schultz, Introduction to WOMEN IN THE WORLD'S LEGAL PROFEsSIONS, supra note 4 , at xxv, xxxvii. They note exceptions, including France, on the high end, and Japan on the low end. Id.

44. Id. at xlii. See also Yuriko Kaminaga \& Jorn Westhoff, Women Lawyers in Japan: Contradictory Factors in Status, in WOMEN IN THE WORLD's LEGAL PROFESSION, supra note 4 , at $467,472-73$ (noting that $19 \%$ of women lawyers working in law firms in Tokyo in 1991 practiced at firms with more than 11 lawyers).

45. Wald, supra note 37 , at 2271 ("The gradual shift from competitive meritocracy to hypercompetitiveness, which began in the mid-1980s, was reflective of changes in practice realities... . Hypercompetitiveness ... portrayed lawyers as near-heroic servants, zealous service providers who pursue the interests of their clients around the clock. Under this new ideology, working 24/7 was considered a badge of honor, proof that lawyers were truly committed to client-centered service."). See also Rhode, supra note 31, at 12 (identifying the relationship of inequality and stereotype).

46. Erhard Blankenburg \& Ulrike Schultz, German Advocates: A Highly Regulated Profession, in LAWYERS IN SocietY: AN OVERview 92, 93 (Richard L. Abel \& Philip S. C. Lewis eds., 1995).

47. See Silver, Shifting Identities, supra note 1, at 1147; Silver, supra note 41, at 17 n.59. 
length of time and stage in life when mobility becomes important. ${ }^{48}$ Global firms also may hire lawyers who, despite lacking certain characteristics typical of their partners and associates, nevertheless offer cultural and language expertise important to the firm. ${ }^{49}$ The global law firm experience for these professionals may garner less credibility when assessed by others, and thus the opportunities to capitalize on a period of work in a global law firm may be limited for these individuals. ${ }^{50}$ Finally, language ability matters in the world of global lawyering. U.S.-based firms still demand that their lawyers be capable of working in English. In this regard, women may benefit from an advantage based on what some suggest is their particularly competitive language ability. ${ }^{51}$

As described earlier, in studying how globalization shapes the human capital dimensions of large law firms, Silver, Phelan, and Rabinowitz found that U.S.-based firms have moved away from reliance on expat lawyers exported from home to staff overseas offices. Instead, the firms combine U.S. and locally-educated and -licensed lawyers in nearly every location. In fact, even where regulation prohibits local lawyers from practicing with foreign law firms, U.S.-based firms have found ways to gain the benefits of local lawyers' expertise. ${ }^{52}$ This might be through the creation of new positions described in terms that do not rely on a law license, such as "advisor," or otherwise avoiding the typical law firm partner-associate terminology. Alternatively, firms in such jurisdictions may prefer local lawyers who also studied in the United States or another jurisdiction as a way to "neutralize" their local

48. See generally Rueyling Tzeng, supra note 11; see also CAROLE SILVER, LAW SCH. Admissions Council, GRANTS REPORT 09-01, AgENTS of GLOBALIZATION IN LAW: PHASE 1 at 5 (2009) (reporting on study of international law graduates who earned LL.Ms in U.S. law schools between 1996 and $2000-34 \%$ of 360 respondents were women); Brigitte Young, Globalization and Shifting Gender Governance Order(s), 4 J. OF Soc. SCI. EDUC. 1, 5 (2005) ("Labor market segmentation into a high-paid 'informational economy' and the expanding informal sector of the 'laboring poor' has increased the disparity among women.").

49. See Carole Silver, The Case of the Foreign Lawyer: Internationalizing the U.S. Legal Profession, 25 FoRdHAM INT'L L.J. 1039 n.92 (2002).

50. See generally Liu, supra note 25 (describing the mobility common for lawyers going between global and local firms); Debra Mao, China's 'Kid' Law Firms Lure Attorneys from U.S., U.K. Rivals, BLOOMBERG (Sept. 27, 2010) http://www.bloomberg.com/news/2010-0927/china-s-kid-law-firms-lure-attorneys-from-london-new-york-competitors.html (reporting on Chinese law firms' hiring of expat and U.S.-educated and -licensed lawyers).

51. Liu, supra note 25 , at 791 .

52. Carole Silver, Local Matters: Internationalizing Strategies For U.S. Law Firms, 14 IND. J. OF GLOBAL LEGAL STUD. 67, 77 n.30 (2007). 
expertise for regulatory purposes. ${ }^{53}$ Women's presence among the ranks of these local lawyers offers an alternative path into elite global firms.

Generally, research on international employment markets indicates, not surprisingly, that women do not participate equally with men regarding international assignments. Nevertheless, this is an essential credential in many businesses: having international working experience is an indication of the ability to work with a multinational workforce, and this is important for advancement. ${ }^{54}$ Scholars have investigated whether women's lower rates of participation in overseas assignments in business settings relate to women not wanting to take expatriate assignments; to their employers not offering them these assignments; or to differences in their treatment in the host country, ${ }^{55}$ such as women not being supported similarly to men and the influence this has on their presence in expatriate roles. ${ }^{56}$

One of the novel approaches of our analysis is to situate gender inequality within the context of globalization in legal practice. 57 While there have been national case studies regarding gender inequality in several countries, ${ }^{58}$ including in the United States, 59 there has been little effort to consider the ways in which globalization may alter national experiences, either through intensifying existing patterns or deploying new ones. ${ }^{60}$ In this article, we draw on an original dataset that provides such insight and focus primarily on the influence of

53. See generally Liu, supra note 25; Silver et.al., supra note 3; Silver, supra note 41.

54. Charles M. Vance, The Personal Quest for Building Global Competence: $A$ Tax-onomy of Self-Initiating Career Path Strategies for Gaining Business Experience Abroad, 40 J.WORLD Bus. 374, 374-75 (2005); Carole Silver, Getting Real About Globalization And Legal Education: Potential And Perspectives For The U.S., 24 STAN. L. \& POL'Y REV. 457, 470-72 (2013).

55. See generally Cynthia Fuchs Epstein, Robert Sauté, Bonnie Oglensky \& Martha Gever, Glass Ceilings and Open Doors: Women's Advancement in the Legal Profession, 64 FORDHAM L. REV. 291(1995) (describing prejudices of foreign clients in regard to women lawyers, but also the ability to overcome such prejudice).

56. See Nancy J. Adler, Global Managers: No Longer Men Alone, 13 INT'L J. HuM. Resource Mgmt. 743 (2002); Arup Varma, Soo Min Toh \& Pawan Budhwar, A New Perspective on the Female Expatriate Experience: The Role of Host Country National Categorization, 41 J. WORLD BUS. 112 (2006).

57. For work on gender and globalization apart from legal practice, see, e.g., Stephanie Seguino, Accounting for Gender in Asian Economic Growth, 6 FEMINIST ECON. 27 (2000) (situating the issue of gender within the economic growth in Asia).

58. See, e.g., JOHN HAGAN \& FIONA KAY, GENDER IN PRACTICE: A STUdy OF LAWYERS' LIVES (1995); WOMEN IN THE WORLD'S LEGAL PROFESSIONS, supra note 4.

59. See DinOVITZER ET AL., supra note 32 .

60. But see Gabriele Plickert \& John Hagan, Professional Work and the Timing of Family Formation Among Young Lawyers in US and German Cities, 18 INT'L J. LEGAL PRoF. 237 (2011). 
globalization on U.S. lawyers. We turn next to a discussion of our data and analytic strategy.

\section{DATA ON GLOBAL LAW FIRMS}

In order to analyze the relationship between gender and professional status in global firms, we collected individual-level, biographical data for lawyers working in overseas offices of U.S.-based law firms. Our dataset was compiled in 2006 and 2007 and consists of professional credentials and characteristics of lawyers. Below we discuss our sampling strategy and describe the dataset.

\section{A. The Sample}

Our data consists of lawyers working at a sample of U.S.-based law firms with an international footprint. These firms are among those often identified as the most successful in the United States in terms of revenue, profits per partner, and size (referring to number of lawyers) ${ }^{61}$ We drew the firms from those listed on the American Lawyer 100 (AmLaw 100) and Global 100 lists of the highest revenue generating firms. Our selection from these lists was shaped by three factors: we began by including every AmLaw 100 or Global 100 (2006) U.S.-based firm that had at least one overseas office; we then eliminated firms that systematically omitted biographical information for lawyers of particular ranks, such as associates. For example, a firm that had a significant global presence but only provided detailed biographies for its partners was not included because we were not confident that a partneronly sample would be representative of a firm's overall approach to global staffing with regard to global issues. ${ }^{62}$ Finally, we eliminated

61. See generally Silver et al., supra note 3 (describing the larger dataset from which our data is drawn).

62. These data have been used as in other work that investigates office dynamics, where the interaction of partners and associates is relevant. See Silver et al., supra note 3. In order to serve both purposes, only firms that provided biographical information on all lawyers, regardless of their status, were included. If firms where only partners' biographical information was available were also included in the dataset, these might have skewed our understanding of the balance between local and expatriate lawyers, and the resulting opportunities offered by globalization, because lawyers with certain credentials may be more likely to occupy partner or associate status, for example. But see Sigrid Quack, Combining National Variety: Internationalisation Strategies of European Law Firms (Mar. 21-22, 2008) (unpublished article presented at American Bar Foundation Symposium: Lawyers and the Construction of the Rule of Law: National and Transnational Processes) (on file with author) (analysis drawn only from partner biographical information). 
firms if we could not determine the proportion of women among associates and partners in the firm's U.S.-home office based on data reported to the National Association of Law Placement (NALP). ${ }^{63}$ Consequently, certain firms that reported gender and status only for the aggregate of their offices were excluded because we could not break out the home office data from the aggregate. Altogether, our sample is comprised of fifty-five U.S.-based law firms.

Our investigation here is further limited geographically. ${ }^{64}$ Specifically, in this study we limit our focus to those jurisdictions in which at least 300 lawyers work in offices supported by the fifty-five firms: Belgium, China, England, France, Germany, Hong Kong, and Japan. We were interested not only in the number of lawyers but also in the size of offices in terms of lawyer headcount because of a concern that smaller offices, particularly one- and two-person offices, might be less likely to house female lawyers. Our selection of jurisdictions reflects this and includes countries in which the largest offices were located so that we would have data lending itself to a meaningful analysis of the status of women. Across these seven countries, the firms employ 6,211 lawyers working in a total of 243 offices. Table 1 shows the number of lawyers and offices in each country included in the study.

\section{Table 1: Distribution of Lawyers and Offices by Jurisdiction}

\begin{tabular}{lll}
\hline \hline & \# of Lawyers & \# of Offices \\
China & 317 & 45 \\
Belgium & 362 & 26 \\
Japan & 432 & 23 \\
Hong Kong & 468 & 28 \\
France & 940 & 23 \\
Germany & 1141 & 48 \\
England & 2551 & 40 \\
Total & 6211 & 243 \\
\hline
\end{tabular}

63. U.S. "home" offices were identified by consulting the NALP listing, the law firm's website, and its history.

64. For an analysis of the lawyers working in all offices of these firms, among others, see Silver et al., supra note 3. 


\section{B. The Dataset}

Our dataset consists of a variety of biographical characteristics on each individual attorney in our sample. We coded for gender, professional status (i.e. partner, associate, counsel), educational credentials (i.e. degree, year earned, country where earned), licensing and bar admission, language and practice focus for each attorney where the information was provided. As the source of information, we relied first on lawyer biographies from law firm websites; where these were incomplete, we consulted other sources, including Martindale-Hubbell, to round out the profile of each lawyer where possible. ${ }^{65}$

Our focus in this article is on lawyers who are expats from the United States, which is one of the groups of lawyers typically included in the global growth strategies of the firms in our study. Generally, these firms draw together three groups of lawyers in their overseas practices: those with local educational credentials and law licenses (we refer to these as "local lawyers" or "host country lawyers"), those with U.S. legal education and admission credentials (as further described below and referred to as "U.S. expats"), and those who were educated and are licensed in a third country (referred to as "other expats"). We differentiate based on the jurisdiction in which the lawyer was educated; admission typically follows legal education, although it is not uncommon for lawyers to be admitted in multiple jurisdictions, including the host jurisdiction. Consequently, we use education as the leading indicator of expatriate or local status. To refine these definitions, we construct the category of "expatriate" lawyers around available information regarding credentials and experiences that provides insight into lawyers' identities. The category of "U.S. expats" includes those lawyers who earned their primary legal education in the United States and earned their undergraduate education in the United States. Taken together, these two credentials indicate U.S. identity with regard to education and lawyering.66 As described earlier, "local"

65. See MARTINDALE.COM, http:/www.martindale.com (last visited Mar. 2, 2013); Attorney Search, N.Y.ST. UNIFIED CT. SYS., https:/iapps.courts.state.ny.us/attorney/Attor neySearch (last visited Mar. 2, 2013).

66. Of course, this may be an over-inclusive definition. In certain countries, for example, it is becoming increasingly common for students interested in becoming lawyers to study in the United States not only for the J.D., but also for the undergraduate degree; the latter increases opportunities to pursue the former in many instances. See generally Nara Schoenberg, Chinese College Students Flock to U.S., CHI. TRIB. (Nov. 19, 2012), http://articles.chicagotribune.com/2012-11-19/news/ct-met-chinese-students-20121119

_1_chinese-students-chinese-system-chinese-equivalent ("Five or 10 years ago, going abroad was considered what dumb rich kids did, and now it's considered what smart middle-class kids do,' said Xueqin Jiang, former director of the international division at 
consists of those lawyers who earned their undergraduate and/or legal education in the same jurisdiction where they currently practice. ${ }^{67}$ For example, an attorney working in London who earned his LL.B at the University of Leicester would be coded as a local lawyer. ${ }^{68}$ Those who are neither local nor U.S. expats fall into the "other expat" category, assuming information regarding their education was available.

\section{The Analytic Strategy}

Our analysis centers on comparing different groups of lawyers (local, U.S. expat and, in certain circumstances, other expat) across jurisdictions to highlight global and gender characteristics, with a particular focus on U.S. expat lawyers. We focus our investigation thematically, relating to two central research questions: first, does the process of globalization affect women and men differently, and, second, is the same gender imbalance that characterizes firms in the United States also present overseas? For each question, we offer both aggregate comparisons across our entire sample of lawyers and also disaggregated by practice location.

\section{TRACKING GLOBALIZATION'S INFLUENCE}

\section{A. Does Globalization Exert an Equal Influence on Men and Women?}

Does the globalization of legal practice provide similar opportunities for men and women to attain status within the profession? To evaluate this question, we focus on partnership as the indicia of status, ${ }^{69}$ comparing men and women across the local and expat groups.

Table 2 shows the breakdown of expats (U.S. and other) and local lawyers along the lines of gender for the aggregated overseas offices in our sample. In general, it shows that the proportion of partners in the overseas offices is highest among the U.S. expat group (46.2 percent of

Peking University High School. . . . The trend appears to be accelerating, Xueqin Jiang said, with Chinese students coming to America to prepare for college while in high school or even middle school."); Silver, supra note 41.

67. In much of the world, legal education is earned at the undergraduate level. See, e.g., LAWYERS IN SOCIETY: AN OvERVIEW (Richard L. Abel \& Philip S. C. Lewis eds., 1996).

68. See, e.g., LLB Law, U. LEICESTER, http://www2.le.ac.uk/departments/law/undergra duate/llb-law-course (last visited Mar. 2, 2013).

69. "Partnership" is an ambiguous term. See DiNOVITZER ET AL., supra note 32, at 14 ("[P]romotion to partnership-is not a realistic possibility until year 8 to 11 , depending on the size of a firm, its geographic location, and the firm structure (whether a firm has nonequity and equity partnerships and the ratio of partners to associates in a firm)."). Nonetheless, it is the best indicator available from the sources of data we use here. 
all U.S. expats are partners compared to 30.8 percent of all local lawyers)..$^{70}$ That is, U.S. expats are more likely to be partners than are local lawyers; in this sense, their expat status is a valuable asset. However, the benefit of being an expat is not equally shared among men and women, as described below.

U.S. expat men and women both are significantly more likely to be partners compared to their local, host country colleagues. But this common advantage disappears when the comparison moves to lawyers in the U.S. home offices of the firms. While U.S. expat men are significantly more likely to be partners than are male lawyers in the home offices of the firms (54.7 percent versus 41.8 percent), there is not a significant difference for female lawyers (22.4 percent versus 17.6 percent)-that is, women who go abroad are not significantly more likely to be partners compared to women who remain at home in the United States. Finally, expat status itself does not erase the inequality that characterizes the home offices of these firms; U.S. expat male lawyers are significantly more likely to be partners than are U.S. expat female lawyers- 54.7 percent of U.S. expat men are partners compared to only 22.4 percent of U.S. expat women. ${ }^{71}$

Table 2: Aggregate Comparisons of Lawyers, by Gender, Status, and National Identity

\begin{tabular}{|c|c|c|c|c|c|c|c|c|c|}
\hline & \multirow{2}{*}{\multicolumn{3}{|c|}{$\begin{array}{l}\text { Overseas Offices } \\
\text { U.S. Expat }\end{array}$}} & \multirow{2}{*}{\multicolumn{3}{|c|}{$\begin{array}{l}\text { Overseas Offices } \\
\text { Local }\end{array}$}} & \multirow{2}{*}{\multicolumn{3}{|c|}{ Home Offices }} \\
\hline & & & & & & & & & \\
\hline & Men & Women & Overall & Men & Women & Overall & Men & Women & Overall \\
\hline Partner & $54.70 \%$ & $22.40 \%$ & $46.20 \%$ & $39.30 \%$ & $13.30 \%$ & $30.80 \%$ & $41.80 \%$ & $17.60 \%$ & $32.80 \%$ \\
\hline Associate & $35.80 \%$ & $71.40 \%$ & $45.20 \%$ & $53.50 \%$ & $78.30 \%$ & $61.70 \%$ & $49.10 \%$ & $71.00 \%$ & $57.10 \%$ \\
\hline Counsel & $9.20 \%$ & $6.30 \%$ & $8.40 \%$ & $6.60 \%$ & $7.30 \%$ & $6.80 \%$ & $9.30 \%$ & $11.50 \%$ & $10.10 \%$ \\
\hline Total & $99.70 \%$ & $100.00 \%$ & $99.80 \%$ & $99.40 \%$ & $98.90 \%$ & $99.20 \%$ & $100.20 \%$ & $100.00 \%$ & $100.00 \%$ \\
\hline
\end{tabular}

70. The comparison of these two groups-U.S. expat partners and local partners-yields a statistically significant difference. We use the term "significant" to indicate a statistically significant difference between the means of two groups. Where appropriate, we conducted a "t-test" to test whether the differences we observed between groups are, in fact, real. In general, it is difficult to find significance in very small samples, which poses a problem for some of our comparisons due to low numbers of lawyers in certain categories; this is especially an issue when we break out the groups by jurisdiction.

71. U.S. male expat lawyers are also less likely to be associates compared to local males and lawyers who remain in the United States (35.8\% vs. $53.5 \%$ and $35.8 \%$ vs. $49.1 \%$, respectively). In contrast, more than $70 \%$ of women are associates across all categories of national identity. 
These comparisons suggest that while there is a benefit to being global (that is, a benefit stemming from U.S. expat status) in the overseas context, it does not translate equally to the United States' market at home. ${ }^{72}$ Both men and women who are U.S. expats enjoy a higher rate of partnership overseas compared to local lawyers, but only U.S. expat men have a significantly higher partnership rate compared to home office colleagues. This is generally consistent with earlier work by Silver finding an absence of interest by U.S. firms in globalizing at home, ${ }^{73}$ but in the analysis that follows, we delve more deeply to investigate whether these same dynamics are at work and whether location influences the effects. Our focus, thus, is on local lawyers and U.S. expats. Together, these two groups comprise more than half of the lawyers in six of the jurisdictions we studied, and more than three-quarters of all the lawyers in each jurisdiction with the exception of Hong Kong and Belgium.

Although the aggregate picture depicted in Table 2 suggests particular preferences and advantages, especially for U.S. male expats, a more nuanced investigation of the power of a global credential is available by exploring these data on a jurisdictional level. Overall, we find a mix of staffing strategies in different jurisdictions, as shown in Table 3, below. For example, when examining the proportion of partners across dimensions of gender and national identity, we find important differences: more local males are partners in England, France, and Germany, while in China, Japan, and Hong Kong the largest group of partners is comprised of U.S. expat men. In Belgium, men in the "other expat" category make up the largest proportion of partners.

These relative positions of local lawyers, U.S. expats, and other expats reflect the particular characteristics of each jurisdiction as well as the dynamics of expansion for the U.S. firms. For example, the lower proportion of U.S. expat partners compared to local partners in Table 3 reflects financial considerations in the sending decision of the firms. On one hand, it is expensive to support U.S. expats overseas; ${ }^{74}$ in addition, expats typically want to return home eventually, resulting in disruptions in office dynamics and client relationships. Each country's regulation of foreign law firms and their relationship to local lawyers

72. Of course, not all home office lawyers are necessarily educated and licensed in the United States. However, for purposes of this analysis, we presume presence in the United States is equivalent to U.S. legal education and bar admission.

73. See Carole Silver, Local Matters: Internationalizing Strategies for U.S. Law Firms, 14 IND. J. GLOBAL LEGAL STUD. 67, 74 (2007) ("Until quite recently, nearly all of the lawyers working for major U.S. law firms earned the basic three-year J.D. degree from a U.S. law school.").

74. Id. at 85-86. 
also plays a role in the ways in which firms staff their overseas offices. As regulations have loosened and global firms have received authority to utilize host country lawyers in many jurisdictions, the balance has shifted toward local lawyers dominating the overseas offices of U.S. and other foreign law firms. ${ }^{75}$ Even where regulation continues to prohibit global firms from hiring local lawyers and advising on local law, however, the presence of local lawyers is still felt. Firms have become accustomed to approaches to global growth that capitalize on local lawyers, and it is common for them to reach beyond regulatory barriers to embed local expertise, either through hiring local lawyers who are carefully characterized as not practicing law for the global firms, ${ }^{76}$ or by staffing with executive office assistants (who may or may not have been formally educated in law) whose professional knowledge and relationships provide important local information. ${ }^{77}$

There are exceptions to this general trend toward local dominance. In Belgium, lawyers in the "other expat" category dominate, which may be a result of the evolution of jurisdictional identity relating to Brussels' role as capital of the European Union, rather than to a more substantive matter. Our approach to coding in Belgium classified only Belgianeducated and -licensed lawyers as "local," while lawyers from other EU countries were coded as "other expats." But more than 90 percent of the "other expat" group in Belgium is comprised of lawyers educated in other EU countries. Thus, the ambiguity of whether "local" should include lawyers from any EU country is reflected in the data in Table 3, and if EU lawyers were considered "local," the pattern in Belgium would reflect that predominating in the other countries. In Hong Kong, in contrast, where local lawyers comprise the smallest group of partners, the issue likely relates to the colonial history and dominant heritage of the English-speaking common law world. More than 72 percent of the "other expat" lawyers were educated in England, Australia, Canada, New Zealand, or Singapore. In both Belgium and Hong Kong, men dominate the "other expat" category.

The dominance of U.S. expats in China may reflect two factors. First, Chinese regulations technically prohibit local lawyers from practicing with foreign law firms, ${ }^{78}$ which included the fifty-five firms studied here. Chinese-licensed lawyers working for foreign firms must not rely on their local practice certificates. Consequently, many local lawyers pursue a second, foreign credential in order to qualify to work as a lawyer with an overseas firm. Additionally, the time period when

75. Silver et al., supra note 3 .

76. See id. at 1442 .

77. Id. at $1442-43$.

78. Liu, supra note 25. 
our data was collected was still quite early in the expansion of U.S. firms into China, and this also may explain some of the disparity regarding the prevalence of U.S. expats there. ${ }^{79}$ The statistics of Japanese offices also reflect the effects of regulatory barriers, which since have been lifted. ${ }^{80}$

Table 3: Comparing National Identity and Gender, by Jurisdiction ${ }^{81}$

\begin{tabular}{lcccccc} 
& $\begin{array}{c}\text { U.S. } \\
\text { Expat } \\
\text { Female } \\
\text { Partners }\end{array}$ & $\begin{array}{c}\text { Local } \\
\text { Female } \\
\text { Partners }\end{array}$ & $\begin{array}{c}\text { Other } \\
\text { Expat } \\
\text { Female } \\
\text { Partners }\end{array}$ & $\begin{array}{c}\text { U.S. } \\
\text { Expat } \\
\text { Male } \\
\text { Partners }\end{array}$ & $\begin{array}{c}\text { Local } \\
\text { Male } \\
\text { Partners }\end{array}$ & $\begin{array}{c}\text { Other } \\
\text { Expat } \\
\text { Male } \\
\text { Partners }\end{array}$ \\
\hline Belgium & $2.2 \%$ & $4.4 \%$ & $6.6 \%$ & $13.2 \%$ & $32.4 \%$ & $41.2 \%$ \\
China & $2.9 \%$ & $7.6 \%$ & $6.7 \%$ & $55.2 \%$ & $9.5 \%$ & $18.1 \%$ \\
England & $3.5 \%$ & $10.5 \%$ & $1.5 \%$ & $18.1 \%$ & $54.8 \%$ & $11.5 \%$ \\
France & $1.8 \%$ & $14.5 \%$ & $0.7 \%$ & $11.3 \%$ & $68.2 \%$ & $3.5 \%$ \\
Germany & $0.2 \%$ & $7.5 \%$ & $0.7 \%$ & $4.1 \%$ & $85.9 \%$ & $1.0 \%$ \\
Japan & $4.7 \%$ & $5.5 \%$ & $1.6 \%$ & $46.5 \%$ & $37.0 \%$ & $3.9 \%$ \\
Hong Kong & $8.4 \%$ & $3.1 \%$ & $7.6 \%$ & $45.8 \%$ & $4.6 \%$ & $30.5 \%$ \\
\hline
\end{tabular}

Overall, Table 3 reflects at least two important themes. The first is male domination in each group of lawyers. The second is that the "local" category does not tend to dominate men as much as it does women. 82

Another way to consider differences and similarities across jurisdictions is by focusing on the likelihood of partnership within each group of lawyers. That is, what proportion of U.S. expats (or U.S. expat women) are partners, and what proportion of local lawyers (or local female lawyers) are partners? This analysis has the potential to suggest an expat, or global, advantage. Table 4 sets out this comparison by jurisdiction and identifies significant differences between U.S. expats and local lawyers within gender groups.

79. See Liu, supra note 25 , at 779-80; Silver, supra note 41 , at 33-34. A new report on women lawyers in China suggests that the bias against women has receded. See Ladies in Justice, CHINA BUS. L.J., Sept. 2012, at 23, 24 ("If anything, "being a woman is a good thing,' says Jeanette Chan, head of Paul Weiss Rifkind Wharton \& Garrison's China practice.").

80. See Silver et al., supra note 3 , at $1456 \mathrm{n} .83$.

81. Each row in Table 3 sums to approximately $100 \%$ (variations result from rounding to the nearest tenth).

82. See Silver, et al., supra note 3, at 1457. 
Table 4: Proportion of Partners Within Each Group of U.S. Expats and Local Lawyers, by Gender

\begin{tabular}{lcccccc}
\hline \hline & $\begin{array}{c}\text { U.S. Expat } \\
\text { Female } \\
\text { Partners }\end{array}$ & $\begin{array}{c}\text { Local } \\
\text { Partners }\end{array}$ & $\begin{array}{c}\text { U.S. Expat } \\
\text { Male } \\
\text { Partners }\end{array}$ & $\begin{array}{c}\text { Local Male } \\
\text { Partners }\end{array}$ \\
\hline Belgium & $60.0 \%$ & $17.1 \%$ & $*$ & $75.0 \%$ & $41.5 \%$ & * \\
China & $27.3 \%$ & $9.3 \%$ & $\pm^{83}$ & $71.6 \%$ & $17.9 \%$ & * \\
England & $19.2 \%$ & $14.1 \%$ & & $53.9 \%$ & $40.6 \%$ & * \\
France & $20.0 \%$ & $13.5 \%$ & $56.1 \%$ & $38.7 \%$ & * \\
Germany & $10.0 \%$ & $13.8 \%$ & $63.0 \%$ & $41.7 \%$ & * \\
Japan & $24.0 \%$ & $11.5 \%$ & $45.0 \%$ & $31.1 \%$ & * \\
Hong Kong & $33.3 \%$ & $7.6 \%$ & $49.2 \%$ & $16.7 \%$ & $*$ \\
\hline
\end{tabular}

In each jurisdiction, U.S. male expats are significantly more likely to be partners compared to local men. That is, U.S. expat men can be more optimistic about partnership status than can local men. This suggests that being an expat is a universal asset for U.S. male lawyers as far as partnership is concerned and regardless of location. However, for women we find very little advantage of being an expat compared to a local lawyer, except in Belgium. ${ }^{84}$ The difference between men and women regarding the universality of an expat benefit suggests that the power regarding partnership status is held by U.S. expat men.

To further hone in on this benefit, we also can consider whether the global expat credential neutralizes gender differences between local male lawyers and expat female lawyers. In each of the jurisdictions except Hong Kong and China, local male lawyers are significantly more likely to be partners compared to local female lawyers. ${ }^{85}$ But perhaps being an expatriate trumps this gender disparity. The analysis set out

83. Here and in subsequent tables (unless noted otherwise), * indicates significance at $\mathrm{p}<.05$ level, + indicates significant at $\mathrm{p}<.10$.

84. Even in Belgium, these results are not necessarily cause for celebration, because the size of the sample of U.S. female expats is exceedingly small.

85. In Hong Kong and China, local females are less likely to be partners than are local males, but the differences are not statistically significant (results are available upon request). This is consistent with a recent report about women lawyers in China, which found that "While it is not possible to ascertain the percentage of female partners in China, there is consensus that although at least as many women as men are entering the profession, for now their representation at partnership level is significantly lower than men and comparable to the trends found in other countries." Ladies in Justice, supra note 79 , at 25 . 
in Table 5 suggests that there is a global effect. The partnership rates for local male lawyers are significantly higher than for U.S. expat women only in three countries: England, ${ }^{86}$ France, and Germany. In all other jurisdictions, there is no significant difference between the two groups. Hong Kong is particularly interesting in this regard: not only is the rate of partnership among U.S. expat women higher than among local men (54.6 percent versus 16.7 percent), but there is a strong presence of other expat women (see Table 3), too. This is consistent with a recent report that women "are no longer a small minority at Hong Kong firms. And they're no longer just populating the lower ranks." 87 In part, this is attributed to "changing social mores," but also to the role of women in powerful client positions. 88 The same report explained that " 35 percent of senior management roles in Hong Kong were held by women, compared to 23 percent in the United Kingdom and 15 percent in the United States." 89 Overall, Table 5 suggests that while the global credential does not provide the same benefit for women as it does for men, it does appear to have some neutralizing effect against gender imbalance in at least a majority of the jurisdictions we studied.

\begin{tabular}{|c|c|c|c|}
\hline & $\begin{array}{l}\text { U.S. Expat Female } \\
\text { Partners }\end{array}$ & Local Male Partners & \\
\hline Belgium & $60.0 \%$ & $41.5 \%$ & \\
\hline China & $27.3 \%$ & $17.9 \%$ & \\
\hline England & $19.2 \%$ & $40.6 \%$ & * \\
\hline France & $20.0 \%$ & $38.70 \%$ & * \\
\hline Germany & $10.0 \%$ & $41.70 \%$ & * \\
\hline Japan & $24.0 \%$ & $31.10 \%$ & \\
\hline Hong Kong & $54.6 \%$ & $16.70 \%$ & \\
\hline
\end{tabular}

The analysis here leaves open several important issues. Our data do not allow an investigation of the relative power of globalization for local

86. According to figures from the Law Society, "[j]ust over one-fifth (21.5\%) of women solicitors in private practice are partners (or partner equivalents), compared with almost one-half of men (49.1\%)." THE LAW SOCIETY, FACT SHEet SERIES 2009: WOMEN SOLICITORS (2010).

87. Jessica Seah, Female Lawyers Find Hong Kong a Good Career Fit, LAw.Com (June 13, 2012, 12:00 AM), http:/www.law.com/jsp/article.jsp?id=1202558150716\&thepage=1.

88. Id.

89. $I d$. 
lawyers. It is possible, as others have suggested, ${ }^{90}$ that being affiliated with a global firm such as the ones in our study provides some benefit to local lawyers that otherwise is unavailable. It is also possible that partnership rates for local lawyers are different in the global firms compared to local peer firms.

Altogether, our findings suggest that globalization affects men and women differently. The real winners appear to be U.S. male expats. Not only are they proportionately advantaged compared to other groups of lawyers overseas (i.e. locals and other expats), but their location overseas also advantages them relative to male lawyers who remain in the United States. Thus, the story here is one of continued gender inequality, with globalization simply supporting, or perhaps increasing, existing divisions.

\section{B. Gender Diversity and Globalization: Diffusion or Local Adaptation?}

In this section, we consider gender diversity with regard to patterns of global growth and ask whether the firms take the same gender imbalances that characterize them in the U.S. with them in their overseas offices. Alternatively, firms may adapt to local conditions, with the relative roles and opportunities available to men and women differing in response to local markets for lawyers. Earlier studies suggest a combination of these dynamics may be most accurate. Specifically, our discussion begins with the question of how being global for U.S. lawyers-that is, having expat status-compares to staying in the United States? Is it potentially advantageous with regard to being a partner for women to move overseas? We alluded to an answer above in the analysis presented in Table 2, where we showed, in the aggregate, that men have a significant benefit compared to women. Although it appears that women also gain an advantage compared to the lawyers in the home offices of the firms-22.4 percent of women are partners in the overseas offices compared to 17.6 percent in the U.S. offices-these differences are not statistically significant. Thus, in the aggregate, it appears that the gender inequality at home diffuses abroad to the global offices as well. But, what does it look like across various national contexts? Are there differences that might suggest an overseas assignment is more advantageous in one jurisdiction than another?

We begin by comparing the relative proportion of partners within male and female U.S. expat groups to their gender counterparts in the

90. See Liu, supra note 25, at 792-94; Swethaa Ballakrishnen, "Why Is Gender a Form of Diversity?": Rising Advantages for Women in Global Indian Law Firms, 20 IND. J. GLOBAL LEGAL STUD. 1261 (2013). 
home offices of the firms. Table 6 compares the proportions of U.S. expat partners by gender to lawyers in the U.S. home offices. For example, in Belgium, 75 percent of all U.S. male expats are partners, which is significantly higher than the 41.8 percent of men who are partners in the U.S. home offices of the firms. In each country, the U.S. expat men have a higher likelihood of being partner than do men who remained in the U.S. However, there is quite a bit of variation across jurisdictions. On the lower end is Japan, where $45 \%$ of all male expats are partners, and on the high end is Belgium, where three out of every four male expats are partners. For women, the story is not as positive. In some jurisdictions, U.S. expat women appear to have a higher likelihood of being a partner compared to women who remained in the U.S., while in others, they actually are less likely to be a partner compared to home office lawyers. For instance, U.S. expat women have the highest likelihood of being a partner in Belgium compared to lawyers in the U.S. (similar to men), but this comparison is not statistically significant. None of the differences shown in Table 6 between U.S. expat women and home office women with regard to partnership is statistically significant. ${ }^{91}$

Table 6: Partnership rates of U.S. expat men and women compared to men and women in U.S. home offices

\begin{tabular}{|c|c|c|c|c|c|c|}
\hline & $\begin{array}{c}\text { Expat } \\
\text { Female } \\
\text { Partners }\end{array}$ & $\begin{array}{l}\text { U.S. Home Office } \\
\text { Female Partners }\end{array}$ & Sig. & $\begin{array}{c}\text { Expat } \\
\text { Male } \\
\text { Partners }\end{array}$ & $\begin{array}{c}\text { U.S. Home Office } \\
\text { Male Partners }\end{array}$ & Sig. \\
\hline Belgium & $60.0 \%$ & $17.6 \%$ & & $75.0 \%$ & $41.8 \%$ & * \\
\hline China & $27.3 \%$ & 1 & & $71.6 \%$ & 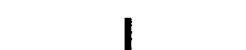 & * \\
\hline England & $19.2 \%$ & & & $53.9 \%$ & & * \\
\hline France & $17.9 \%$ & & & $56.1 \%$ & & * \\
\hline Germany & $11.1 \%$ & & & $63.0 \%$ & & * \\
\hline Japan & $23.1 \%$ & $V$ & & $45.0 \%$ & 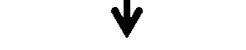 & \\
\hline Hong Kong & $33.3 \%$ & & + & $49.2 \%$ & & \\
\hline
\end{tabular}

91. In Hong Kong, this difference is marginally significant. The general absence of significance is largely due to the small number of women that are U.S. expats and partners to begin with. In Belgium, for example, there are only five women expats and three of them happen to be partners. Thus, although the statistic appears high for this group $(60 \%)$, it is not a large enough difference for it to be statistically significant. 
Another way to consider the uniformity or difference among jurisdictions with regard to partnership status of men and women is to analyze the proportion of all partners by gender for both U.S. expats and those who work in the U.S., as shown in Table 7. Measured this way, we can see wider divergences between representation at home and in overseas offices with regard to partnership. Women constitute 20 percent of all partners in the home offices of firms, but the U.S. expat female group comprises only small proportions of all partners in overseas offices. For example, in Belgium, 3.4 percent of all partners are U.S. expat women. In the home offices, men represent 80 percent of all partners and, similar to the women, the U.S. male expats also represent smaller proportions abroad. However, the range of values for U.S. expat males is much wider than for women, ranging from 1.9 percent in Germany to 33.1 percent in China. This simply reaffirms that U.S. expats occupy a marginal role overseas in terms of numbers, but within this U.S. expat category, men are represented at higher levels. The imbalance between men and women within the U.S. expat partner groups raises important questions for future research, including the criteria firms use in deciding who is sent abroad and the gender characteristics of lateral markets of U.S. expats in these countries.

Table 7: Relative proportion of overseas partners who are U.S. expat men and women, compared to proportion of U.S. home office partners who are men and women

$\begin{array}{cccc}\text { Expat } & \text { U.S. Home } & \text { Expat } & \text { U.S. Home } \\ \text { Female } & \text { Office Female } & \text { Male } & \text { Office Male } \\ \text { Partners } & \text { Partners } & \text { Partners } & \text { Partners }\end{array}$

\begin{tabular}{|c|c|c|c|c|c|c|}
\hline & & & $\mathrm{Si}$ & & & Sig. \\
\hline Belgium & $3.4 \%$ & $20.0 \%$ & * & $6.7 \%$ & $80.0 \%$ & * \\
\hline China & $2.5 \%$ & & * & $33.1 \%$ & | & * \\
\hline England & $3.1 \%$ & & * & $15.9 \%$ & & * \\
\hline France & $1.4 \%$ & & * & $5.6 \%$ & & * \\
\hline Germany & $0.4 \%$ & & * & $1.9 \%$ & & * \\
\hline Japan & $5.9 \%$ & & * & $19.0 \%$ & & * \\
\hline Hong Kong & $6.7 \%$ & 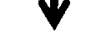 & * & $21.2 \%$ & & * \\
\hline
\end{tabular}


Overall, these analyses suggest a glocal approach regarding gender diversity. On one hand, U.S. expat men dominate U.S. expat women in each jurisdiction, both with regard to the proportion of partners within each of these groups and the proportion of all partners in the jurisdiction. In comparison with the U.S. home office lawyers, being an expat is an advantage for men regarding partnership status, but it is not statistically significant for women. It appears that gender inequality continues to exist for women at the partnership level in overseas offices just as it does in the United States, suggesting that the firms take their home inequalities abroad. However, this process is mediated by location-the local context also matters.

\section{ELUSIVE OPPORTUNITIES}

As U.S.-based law firms invest in global growth, they have transformed from thoroughly and solely U.S.-centric entities into organizations that recognize and include expertise arising from credentials, education, and relationships based outside of the United States, too. In doing so, they have expanded their hiring criteria to include local lawyers in every jurisdiction where local regulation permits and even, in some instances, where it does not. This shift toward a more global approach to assessing the credentials and expertise of lawyers offers an opportunity to upend traditional hiring criteria that reinforce existing hierarchies in the profession. Women, both local and expatriate, may benefit from opportunities to circumvent their current professional labor markets; for local lawyers, this may involve moving into foreign firms that compete with local law firms for talent as well as for clients, while expat women may attempt to avoid the strictures of U.S. hiring and promotion patterns by moving overseas.

Our preliminary analysis of the credentials of overseas office lawyers indicates that the gender inequality characteristic of the U.S. home offices of our firms, as well as of large corporate U.S. law firms generally, also is reflected in many of the overseas offices. While U.S. expats are more likely to be partners compared to local lawyers in most jurisdictions, the gender gap between men and women persists in the expat group. But staffing is not uniform across jurisdictions and the focus of practice in one location may result in a preference for expats or, more likely, a disinclination toward local lawyers. Local regulatory barriers in certain jurisdictions such as China may reinforce this disfavor. Thus, while globalization creates opportunities for lawyers educated and licensed outside of the United States to join forces with U.S.-based law firms, it does not necessarily neutralize the burden of gender. Outside of those jurisdictions that generally favor expatriates 
over local lawyers (see, for example, Table 4), the typical pattern of male dominance seems to persist.

U.S. law firms have approached global growth by slowly moving from the goal of uniformity with regard to their lawyers' credentials, training, and expertise to an appreciation of national differences. ${ }^{92}$ But is this broadening of vision sufficient to allow women to gain parity with their male colleagues? Our work so far suggests that globalization has not leveled the playing field in most instances, and in fact at times reinforces gender divisions-even extending them. This is not surprising in light of the role globalization plays in deepening existing divisions in other contexts, but it is disappointing. ${ }^{93}$

\section{CONCLUSION}

Our research suggests that gender inequality is not erased by globalization. Indeed, it may be reinforced in certain contexts. But these findings are only a first step in understanding the forces that bring together globalization and gender diversity. While our data provide much insight, they also leave important questions unanswered. These include the point in their careers at which lawyers move overseas and the circumstances surrounding their affiliation with these firms. The decision-making processes surrounding staffing decisions, including the site of such decisions within firms (whether in a central home-office or in the locale where the hire will work) also may shape the opportunities available to women. Regulation is one, as is the history of an office's development, local norms regarding lateral moves and a firm's tolerance for risk, among other factors. The small number of U.S. expat lawyers in the overseas offices we have studied may mask important forces, and differences among firms and cities also may be significant. Each of these issues deserves additional research.

In addition, our hope is that collaborations such as the one reflected in this symposium issue will facilitate the exploration of comparative effects on local and expatriate women lawyers who join local and foreign law firms, among other kinds of practice organizations. Perhaps by shining additional and continuous light on experiences of diverse lawyers, progress follow.

92. See Silver, Shifting Identities, supra note 1, at 1146 (discussing firms' projections of uniformity as their hallmark).

93. See Carroll Seron, What Is Happening to Women in the Legal Profession?, NEW LEGAL REALISM CONVERSATIONS (Nov. 30, 2012), http://newlegalrealism.wordpress.com/20 12/11/30/women-in-the-legal-profession-carroll-seron-blog-forum/ ("The upper reaches of power and decision making within the legal profession, especially, remain disproportionately inaccessible or ascribed by status markers of gender and race."). 
